\title{
Modelling the permafrost distribution in steep rock walls in Norway
}

\author{
Céline Steiger ${ }^{1}$, Bernd Etzelmüller' ${ }^{1}$ Sebastian Westermann ${ }^{1} \&$ Kristin S. Myhra' \\ ${ }^{1}$ Department of Geosciences, University of Oslo, P.O. Box 1047, 0316 Oslo, Norway. \\ E-mail corresponding author (Bernd Etzelmüller): bernde@geo.uio.no
}

\begin{abstract}
In many cold mountain areas, permafrost is a key factor for the stability of rock walls. This study provides a regional assessment of potential permafrost occurrence in steep rock walls in Norway. We present a map of steep rock walls with possible permafrost occurrence for Norway. This map is created from interpolated and gridded surface air temperature data and a terrain analysis based on a $10 \mathrm{~m}$ digital elevation model (DEM). The results are evaluated against field observations, a rock glacier inventory and local rock-wall temperature measurements. We show that permafrost in steep rock walls is found in around 9\% of all the steep rock walls in Norway. Most frequently these are found in central southern Norway and in the LyngenKåfjord area in northern Norway. The study discusses the spatial distribution pattern of permafrost rock walls, and shows that in northern Norway mapped rock-slope failures are in close association with permafrost rock walls.
\end{abstract}

Keywords: Mountain permafrost, rock walls, GIS, geomorphology, hazard assessment

Received 21. April 2016 / Accepted 18. October 2016 / Published online 6. December 2016

\section{Introduction}

Permafrost is thermally defined and therefore particularly sensitive to climatic changes. During recent decades, permafrost has gradually thawed across the Northern Hemisphere (cf., Romanovsky et al., 2010) in response to the general warming trend since the end of the Little Ice Age (e.g., Lilleøren et al., 2012).

It is well documented that cryospheric processes influence the stability of steep rock slopes (e.g., Davies et al., 2001; Gruber \& Haeberli, 2007; Fischer et al., 2012; Krautblatter et al., 2013). In cold environments, freeze-thaw cycles and preservation of large temperature gradients (Hallet et al., 1991) lead to a build-up of ice in rock joints, which favour frost weathering, but may also stabilise rock walls against more deep-seated failures. However, ice close to the melting point becomes weak and deformable, so that movement and subsequent failure can occur (e.g., Davies et al., 2001). Further on, the stability of rock material is a function of temperature (Krautblatter et al., 2013), with higher shear and tensile strength values when frozen. Thus, the thawing and degradation of permafrost in steep rock walls can contribute to trigger rockslides which have been investigated especially in the French and Swiss Alps (e.g., Ravanel \& Deline, 2011; Fischer et al., 2012).

In Norway, permafrost is widespread in the high mountain areas of the Scandes (e.g., Gisnås et al., 2013; Westermann et al., 2013). Despite the importance of permafrost for rock-slope movement and failures (e.g., Blikra \& Christiansen, 2014), no systematic estimation of permafrost occurrence in steep slopes has yet been performed in Norway. This study provides a first evaluation of the distribution of steep permafrost rock walls in Norway by applying a simple spatial modelling scheme, and discusses the spatial distribution pattern and possible influence on rock-slope failures. 


\section{Settings}

Norway covers a land area of $c \cdot 350,000 \mathrm{~km}^{2}$, and its topography is dominated by the mountain chain of the Scandes, stretching from $57^{\circ} \mathrm{N}-71^{\circ} \mathrm{N}$ through Norway and Sweden over a distance of more than 2000 $\mathrm{km}$. Scandinavia forms a tilted passive margin, where highest elevations are found towards the western coast, decreasing towards the east and the Bothnian Sea (e.g., Gabrielsen et al., 2010). The area has undergone multiple glaciations during the Pleistocene, with the largest glaciations covering the whole of northern Europe several times during the last $c .1$ Mio. yrs (e.g., Hughes et al., 2016). The glaciations have produced steep valley sides associated with large U-shaped valleys which drained the ice sheets. Further, local cirque glaciations formed rock walls, mostly located along the western coast of the country and within the highest mountain regions of central southern Norway (e.g., Sollid \& Sørbel, 1979). A classification of topography over Norway shows that most of the permafrost areas are located in landscape types which are not classified as typical alpine relief, but in high altitude areas dominated by plateaus and relatively smooth-relief mountains ('paleic surfaces', e.g., Gjessing (1967)) partly dissected by local glaciations (Etzelmüller et al., 2007a).

In general, the lower limit of mountain permafrost in Scandinavia decreases from west to east, from $c .1600 \mathrm{~m}$ a.s.l. to $c .1300 \mathrm{~m}$ a.s.l. in southern Norway (e.g., King, 1986; Etzelmüller et al., 2003; Farbrot et al., 2011; Gisnås et al., 2013) and from c. $900 \mathrm{~m}$ a.s.l. to $c .500 \mathrm{~m}$ a.s.l. in northern Norway including northwestern Sweden (e.g., Christiansen et al., 2010; Farbrot et al., 2013; Gisnås et al., 2013). These gradients are controlled by the climatic setting, with the maritime climate along the western coast gradually changing towards a more continental climate in the eastern parts of Norway.

\section{Data and methods}

\section{Basic data used for the analysis}

For the simulation and analysis of steep rock walls which may be underlain by permafrost, four datasets are used: 1. For the temperature forcing we used interpolated and subsequently gridded data of daily air temperature with a resolution of $1 \mathrm{~km}$ (Tveito et al., 2000; seNorge version 1.1., hereafter referred to as seNorge data). The seNorge dataset is based on daily temperature measurements from about 200 stations, where measured daily mean values are first projected to sea level at the station positions. Residual kriging is then applied for spatial interpolation of the de-trended temperatures, before the interpolated temperatures are readjusted to terrain altitude using a 1-km digital elevation model (@ Statens Kartverk). The lapse rates used for the altitude projections are derived from monthly mean temperature data from 1152 stations in northern Europe using stepwise linear regression (Tveito et al., 2000). This dataset has been validated and used in various studies earlier (e.g., Saloranta, 2012), included as forcing for permafrost models of Norway (Farbrot et al., 2013; Gisnås et al., 2013; Westermann et al., 2013). For our study we calculated an average of the daily temperatures for the normal period 1961-1990 for each grid cell, defining the mean annual air temperature (MAAT) for this period. Such datasets are frequently used as an important predictor for permafrost occurrence in studies over larger regions (e.g., Etzelmüller et al., 2003, 2007b).

2. For the country-wide identification of steep rock walls we used a digital elevation model (DEM) with a ground resolution of $10 \mathrm{~m}$ (๔ Statens Kartverk, Norway). The high resolution ensures the reliable identification of steep rock walls based on simple terrain analysis. In this study, we defined rock walls as cells in the DEM with a calculated slope value of $\geq 60^{\circ}$, where slope is calculated based on the scheme proposed by Zevenberge \& Thorne (1987), implemented in ArcGIS (C) ESRI). As this algorithm includes spatial averaging, the cut-off value used is assumed to be a close approximation for steep rock walls.

3. Rock-wall temperatures are depending on the topographic aspect or exposure of the rock wall. Southerly slopes receive more direct radiation than slopes directed towards north. A measure for the relative importance of topographic aspect on the surface energy balance in a slope is the potential incoming short-wave radiation (PISWR), which can be calculated purely on the base of a DEM (e.g., Etzelmüller et al., 2001). For this calculation we used the procedures published in $\mathrm{Fu} \&$ Rich (1999), implemented in ArcGIS (@ ESRI).

4. For the evaluation of the influence of topographic aspect on potential permafrost distribution in rock walls, temperature measurements are required. Such longerterm temperature measurements are available from only five rock walls in central Jotunheimen, southern Norway. There, five temperature loggers are installed at a depth of up to $10 \mathrm{~cm}$ in vertical rock walls with varying topographic aspect (Hipp et al., 2014). Geoprecision $M$-Log5W-ROCK (๑) rock-wall loggers were used. These have measured temperatures every two hours since 2009 for one site and since 2010 for the other four sites, with an accuracy of $\pm 0.05^{\circ} \mathrm{C}$ and a resolution of $0.01^{\circ} \mathrm{C}$. Up to 2013 the settings and data were published in Hipp et al. (2014), but for this study we applied data for two more years until 2015, which were used to give a new and probably more accurate estimate of aspect dependency of temperature in this area based on a longer data record. The longer data series also allowed for an evaluation of seasonal changes. 


\section{Modelling permafrost in steep rock walls}

MAAT in steep rock walls - To address potential permafrost in steep rock walls, we combined the MAAT map based on seNorge with the DEM. We produced a temperature dataset at a spatial resolution of $10 \mathrm{~m}$ by interpolating the MAAT dataset from $1 \mathrm{~km}$ to $10 \mathrm{~m}$ with a continuous lapse rate of $0.44^{\circ} \mathrm{C} 100 \mathrm{~m}^{-1}$, using the $10-\mathrm{m}$-DEM. The lapse rate value is the yearly average of the applied lapse rate for the generation of the monthly temperature datasets of seNorge (Tveito et al., 2000). For coast-near areas in Norway the value is probably too low, while for more continental areas the value could even be too high. As most steep slopes are located in the more maritime settings of Norway, this estimate is justified and can be considered as conservative.

Permafrost in steep rock walls - For identifying potential rock walls in permafrost, a threshold relationship between possible permafrost and MAAT must be defined. We assume that the surface cover (snow, vegetation and debris) in rock walls is thin to absent. Thus, for simplicity we neglect surface temperature offsets due to snow or vegetation in this study. Furthermore, increasing short-wave solar radiation, e.g., due to topographic aspect or seasonality, has a warming influence on the temperature of the rock walls (e.g., Gruber et al., 2004). Rock-wall surface temperature measurements from the Jotunheimen area, southern Norway, indicate that northfacing rock-wall surfaces are on the annual average $1^{\circ} \mathrm{C}$ while south-facing slopes are $3^{\circ} \mathrm{C}$ warmer than the air temperature (Hipp et al., 2014). Therefore, we applied an average surface offset of $-2^{\circ} \mathrm{C}$ (average of the surface offset of -1 and $-3^{\circ} \mathrm{C}$ ) as a threshold for the potential existence of permafrost in rock walls, independent of rock-wall aspect.

The influence of topographic aspect - To evaluate the influence of topographic aspect on the rock-wall surface temperatures $\left(T_{R W}\left({ }^{\circ} \mathrm{C}\right)\right)$, we simply recalculated the linear regression analysis presented in Hipp et al. (2014) with the longer and updated dataset. The multiple linear regression relates the rock-wall surface temperature, to elevation $(Z)$ on a $10 \mathrm{~m}$ resolution, and potential incoming short-wave radiation (PISWR) calculated based on the DEM. Contrary to Hipp et al. (2014) we divided the dataset into the four 'standard' seasons (DJF, MAM, JJA, SON) of a year, which gave a degree of freedom of 69 for the multiple regression analysis. We then defined the average rock-wall temperature $\left(T_{R W}\right.$ in $\left.{ }^{\circ} \mathrm{C}\right)$ as the dependant variable, and $Z(m)$ and PISWR $\left(W m^{-1}\right)$ as the independent variable. Here, $Z$ was kept constant for the five logger positions, while PISWR varied with the season, solving the equation for each season:

$$
T_{R W}=a+b \times P I S W R+c \times Z
$$

where $a, b$ and $c$ are regression coefficients. This resulted in a continuous temperature field of rock-wall surface temperatures for each season. The cells with an average temperature $\leq 0^{\circ} \mathrm{C}$ during the observation period (2009-2015) and a slope angle $\geq 60^{\circ}$ were subsequently extracted. The topographic aspect and $Z$ of each cell located at temperatures between $0^{\circ} \mathrm{C}$ and $-1{ }^{\circ} \mathrm{C}$ were selected to define the lower limit of permafrost at different topographic aspects. Finally, we carried out a Hierarchical Partitioning Analysis which calculates goodness of fit measures for the entire hierarchy of models using all combinations of our two independent variables (Walsh \& Mac Nally, 2008). Based on the list of goodness of fit measures an algorithm developed by Chevan \& Sutherland (1991) is applied, estimating the contribution for each variable (in our case: PISWR and $Z)$ to the model. All statistical analyses were performed in the $R$ statistical computing environment (R Core Team, 2015).

\section{Results}

\section{Country-wide assessment}

Through this study, we have estimated that around $9 \%$ of steep rock walls in Norway are underlain by permafrost. In southern Norway, the highest frequency of permafrost rock walls occurs in the mountain area surrounding the inner parts of Sognefjorden and Jostedalsbreen, along with high-elevation areas in Møre-Romsdal (Fig. 1). The average lower limit of permafrost in such rock walls was modelled to $c .1550$ $\mathrm{m}$ a.s.l. in the west and down to $1350 \mathrm{~m}$ a.s.l. in more central parts of southern Norway. High permafrost occurrences can be found in high-mountain areas dominated by present or late-Pleistocene cirque glaciation, such as the Hurrungane, Rondane and Dovre mountain areas. There, several areas show frequencies of permafrost rock walls $>10 \%$ within a $1 \mathrm{~km}^{2}$ area (Fig. 1). In northern Norway, similar frequencies are found for the Lyngen Alps and Kåfjord area (Fig. 1), with lower permafrost limits of around $850 \mathrm{~m}$ a.s.l. The modelling also suggests steep permafrost slopes close to the western Varanger Peninsula at elevations close to sea level and in large canyons like the canyon of the lower Alta River in Finnmark or the Raisa River in northern Troms.

\section{Regional assessment}

The regression equation (1) applied for the different seasons obtained from the rock-wall temperature measurements showed that all were significant $(p<$ 0.01 ). The highest fit with $R^{2}$-values between 0.6 and 0.7 were obtained during autumn and spring, while low $R^{2}$-values between 0.2 and 0.4 were found during summer and winter, respectively. The data showed that 


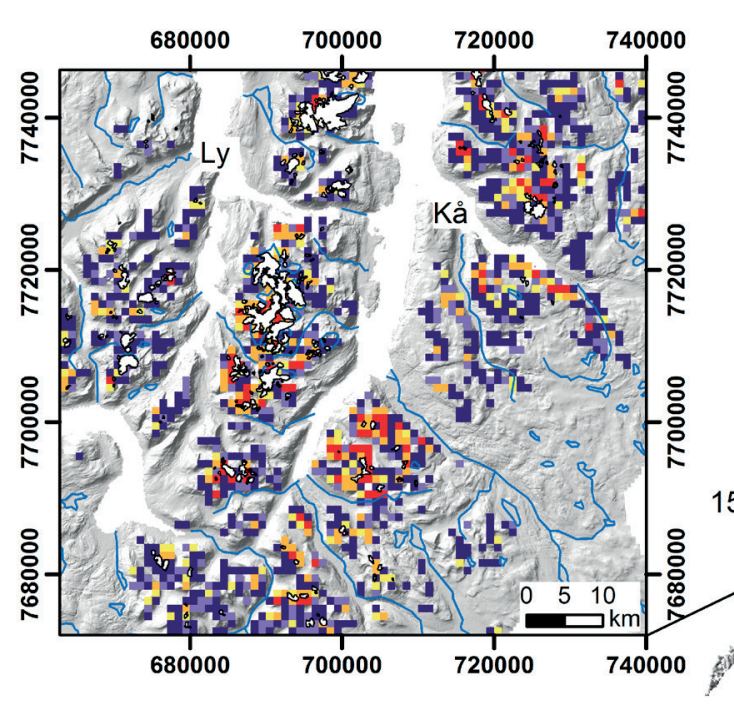

TOP OF FIGURE

\section{Frequency distribution (in \%)}

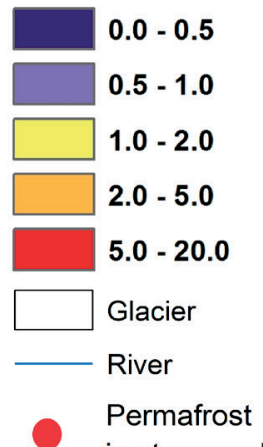

Permafrost
in steep rock walls
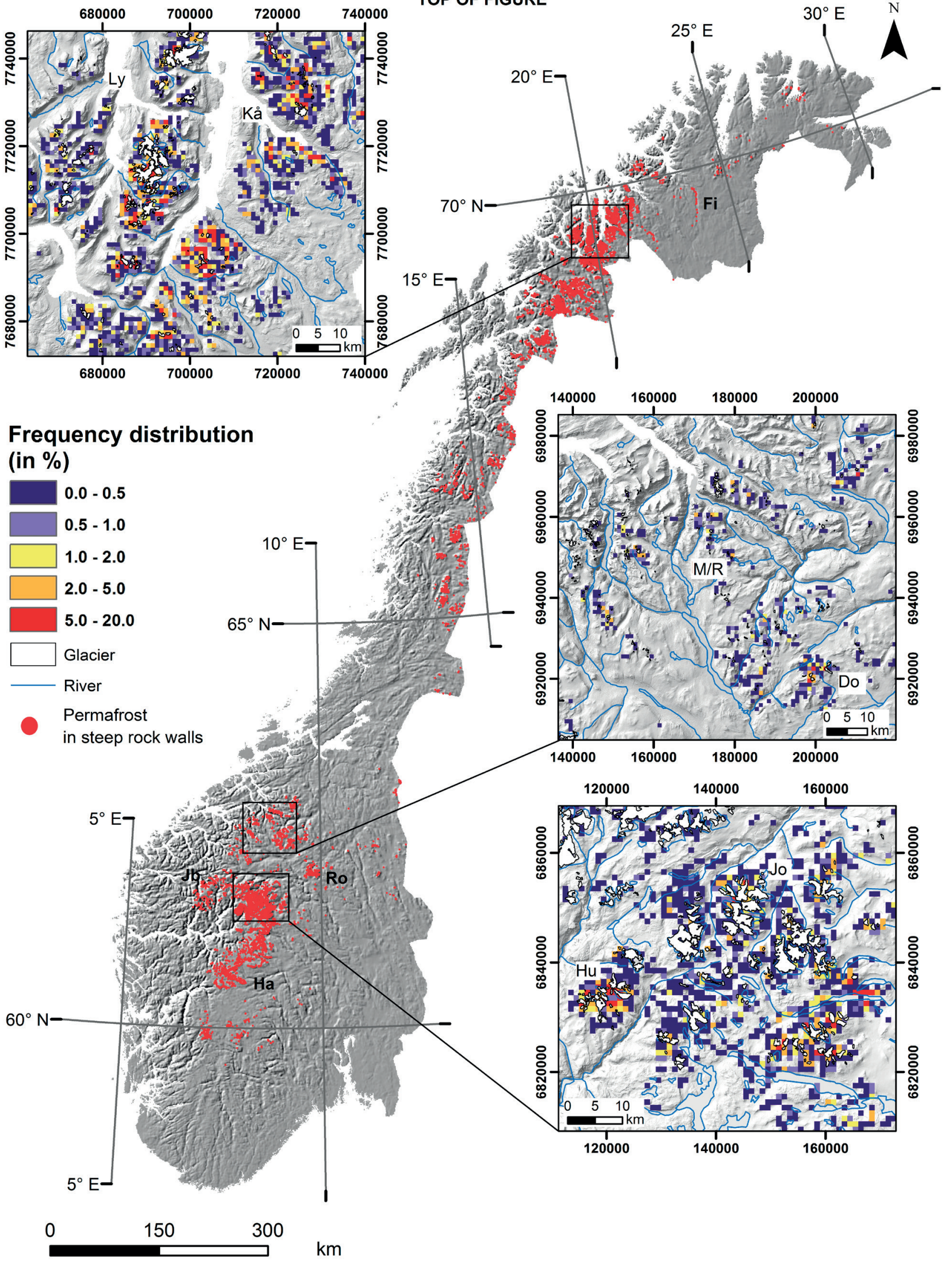

$70^{\circ} \mathrm{N}$
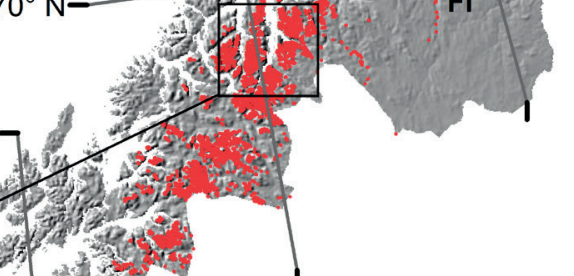
the modelled rock-wall surface temperature depends on both $Z$ and PISWR, and the hierarchical partitioning analysis indicates that only during winter PISWR is less important than elevation for rock-wall temperatures. This demonstrates the very low influence of PISWR during winter due to the high latitude, with low sun angle and associated strong shading from surrounding mountains.

The lower limit of permafrost in the Jotunheimen area is around $1800-1950 \mathrm{~m}$ a.s.l. for southerly rock walls, around 1250-1400 $\mathrm{m}$ a.s.l. for northerly rock walls and around 1500-1650 m a.s.l. for east- and west-facing rock walls (Fig. 2). This indicates a topographic aspect dependency of permafrost occurrence of around 500$600 \mathrm{~m}$. In comparison, the regional estimate of the lower limit of permafrost (Fig. 1) which does not consider the influence of topographic aspect is nearly constant at an elevation of around $1450 \mathrm{~m}$ a.s.l. for all topographic aspects in this area. Thus, the regional assumption with an average $-2^{\circ} \mathrm{C}$-threshold seems valid within $c .100 \mathrm{~m}$ for all aspects except southerly exposed slopes, where our analysis indicates a permafrost limit which is too low by approximately $400 \mathrm{~m}$.
At present, new rock-wall surface temperature data from other parts of Norway have been acquired but not yet analysed; thus, the topographic aspect dependency of lower permafrost limits can today only be applied for the central parts of southern Norway. A correction of our modelling result with possible permafrost occurrence in the Jothunheimen area, based on the data including aspect dependency, leads to a reduction of the total area as demonstrated in Fig. 3.

\section{Discussion}

\section{Evaluation of the study}

The new map presented here shows a first countrywide modelling of sites with steep rock walls potentially containing permafrost in Norway. The map is a gross simplification as the influence of topographic aspect is only partly evaluated. Furthermore, the map is based on a simple modelling approach with interpolated

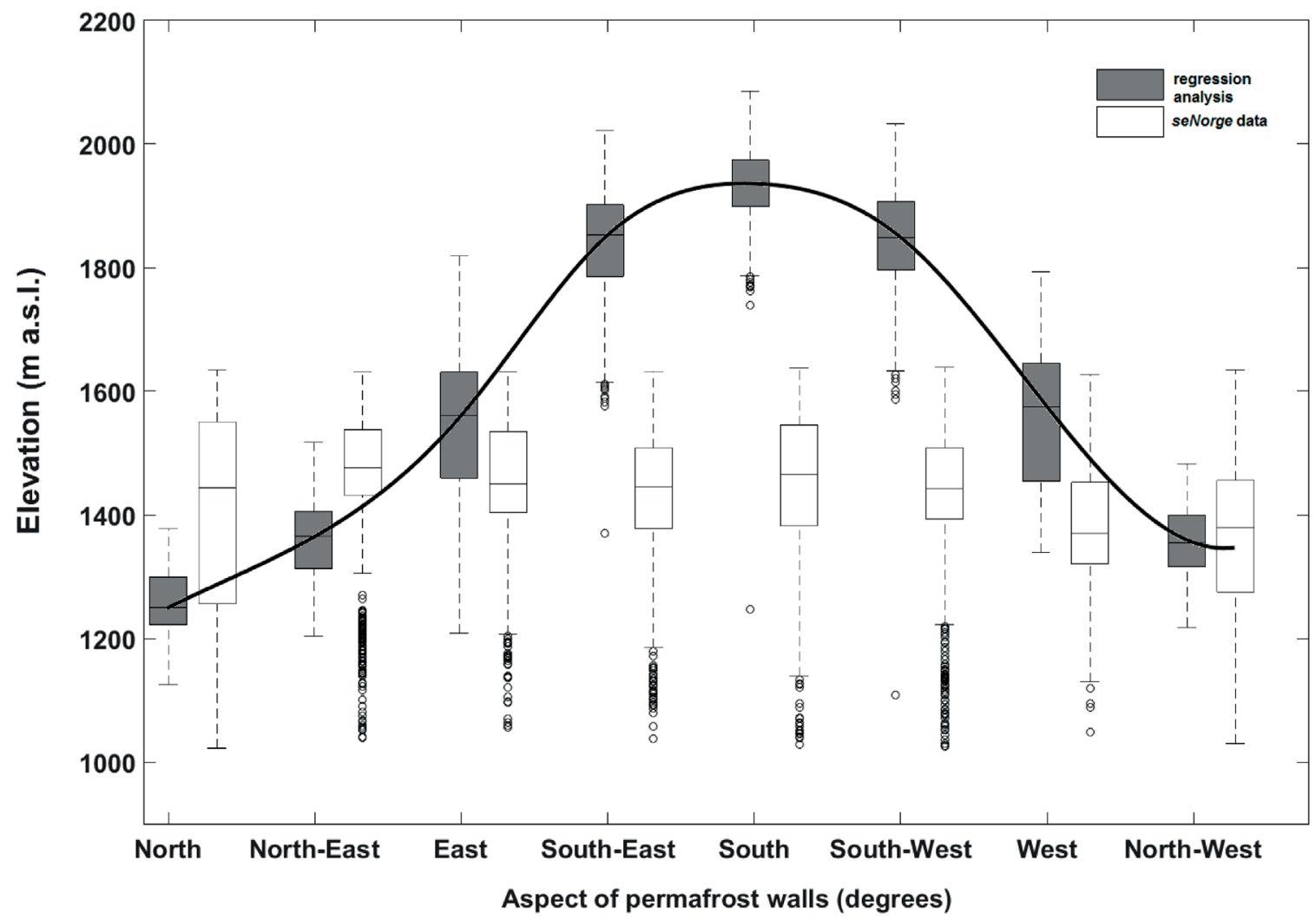

Figure 2. Box plot (median and 25\% / 75\% quartiles) for modelled permafrost occurrences in the Jotunheimen area. The grey-shaded boxes describe the aspect-dependency of rock-wall permafrost abundancies, based on the multiple regression between measured rock-wall surface temperature and environmental parameters. The white boxes show the same information based on the map of modelled potential permafrost occurrence (Fig. 1), where the influence of topographic aspect is not included. The spread and distribution of extremes for the multiple regression result within the different topographic aspect classes are relatively uniform for all bins, while for the 'seNorge' result there seems to be an overweight to lower extreme values. This pattern is probably related to quality issues of the $1 \mathrm{~km}$ and the $10 \mathrm{~m}$ DEM, but has not been investigated in detail. 


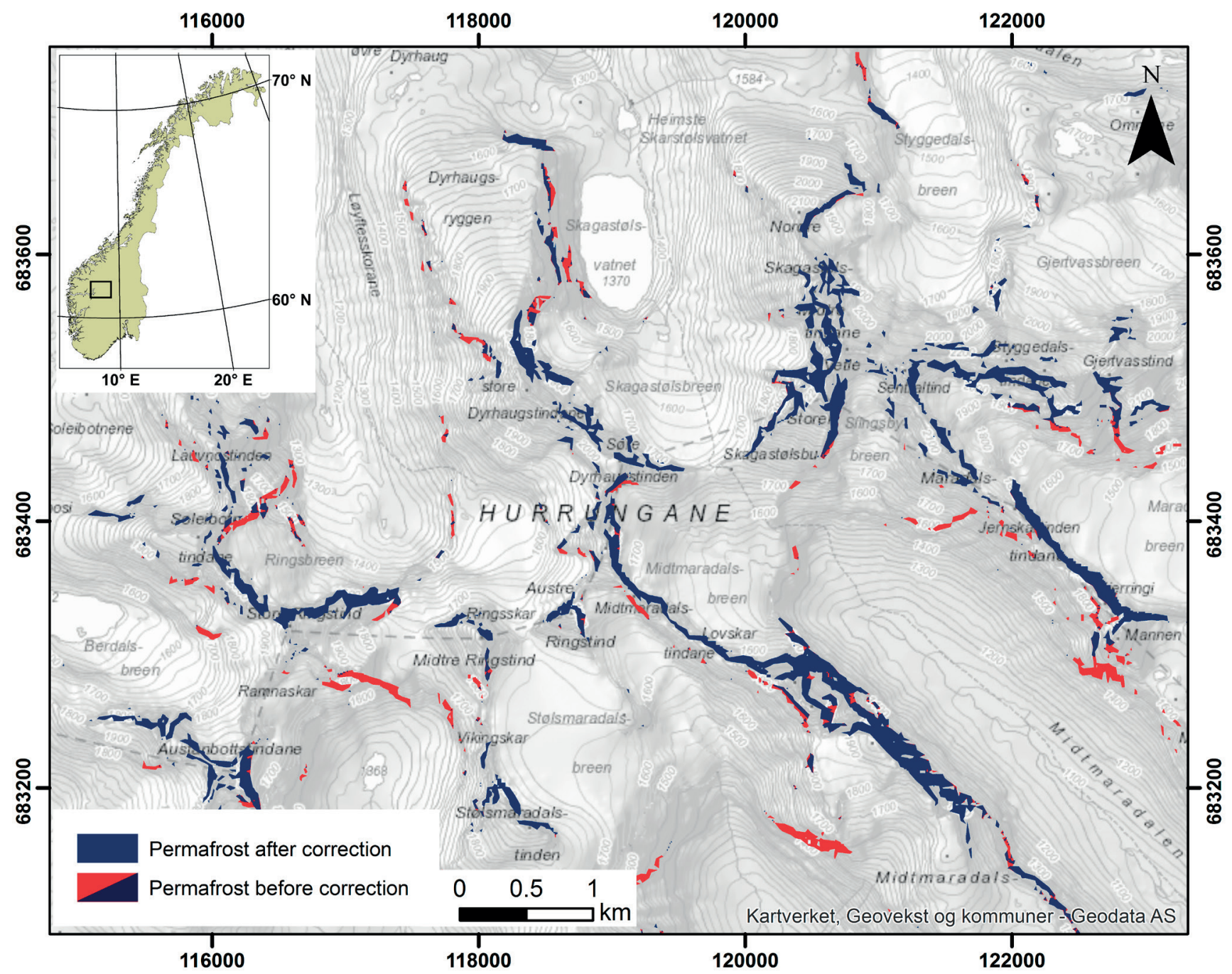

Figure 3. The figure shows the difference between total modelled permafrost occurrences in the Jotunheimen area (in red), and those corrected after including topographic aspect dependencies based on the multiple regression (in blue only). Including the topographic aspect reduces the total area of modelled rock-wall permafrost.

and gridded meteorological data. At higher elevations, meteorological stations are sparse in Norway, and the extrapolation method is strongly dependent on the temperature lapse rate (Tveito et al., 2005). In Norway, $85 \%$ of all climate stations are installed below $500 \mathrm{~m}$ a.s.l., whereas $50 \%$ of the terrain is above this altitude (Tveito et al., 2005). Meteorological conditions, including inversions, affect the temperature regime and produce biases towards lower temperatures for the interpolated seNorge dataset at high elevations. Further, applying a constant lapse rate of $0.44^{\circ} \mathrm{C} 100 \mathrm{~m}^{-1}$ for the MAAT assessment on $10 \mathrm{~m}$ resolution is a simple approximation, which does not account for regional topographic and climatological differences. Finally, snow accumulation in irregular rock walls was not included in the analysis, though studies indicate that steep rock walls may be partly snow covered, which may induce both cooling and warming of the rock wall depending on snow depth and timing of the snow cover (e.g., Hasler et al., 2011; Haberkorn et al., 2015).
Our regional assessment includes the impact of topographic aspect using empirical relations between rock-wall surface temperatures and elevation and PISWR, respectively. For the purpose of this study, we argue that this approach is appropriate even if the problem is dependent on the local energy balance conditions. The calculated PISWR does not account for cloudiness, back scattering and reflection (albedo) from, e.g., snow fields, glaciers or opposing rock walls (e.g., Magnin et al., 2016). However, the empirical assessment provides a realistic aspect-dependency of the lower limit of permafrost in steep slopes of 500-600 m between north- and south-facing slopes. Our estimates are lower than results obtained in the Alps, where values of around $1000 \mathrm{~m}$ were obtained for the aspect-controlled influence on distribution of permafrost in steep rock walls (cf., Gruber et al., 2004). The main reason for this difference is related to (1) lower radiative energy because Norway is located at higher latitudes compared to the Alps; (2) the lower sun inclination in winter, prohibiting aspect differences in PISWR; and (3) higher cloudiness in the 
more maritime climate of Norway, enhancing the effect of topographically independent long-wave radiation and sensible and latent heat fluxes on the surface energy balance.

A comparison of the results presented here with the simple country-wide assessment, with a cut-off value of $-2^{\circ} \mathrm{C}$ and an empirical model based on field observations, indicates a satisfactory agreement. The cut-off value in Jotunheimen is not conservative, and seems to be too cold for the southerly oriented slopes. However, other topographic aspects are represented within a much lower uncertainty $(<200 \mathrm{~m})$, which is satisfactory for a country-wide assessment. The result fits well with the numerical permafrost models developed for Norway (Gisnås et al., 2013; Westermann et al., 2013). However, the comparison is not independent as the same forcing data were used (seNorge), and the spatial resolution of the modelling is $1 \mathrm{~km}$.

For an independent evaluation of this country-wide assessment, a recent inventory of rock glacier and icecored moraines by Lilleøren \& Etzelmüller (2011) was used. Active rock glaciers and certain types of ice-cored moraines indicate permafrost, and are normally situated close to, or in the vicinity of steep rock walls so that they can develop due to weathering material falling from the rock walls. Comparing our results with this inventory indicates a reasonable visual fit (Fig. 4). In contrast to the Alps (e.g., Boeckli et al., 2012), talus-derived rock glaciers are quite infrequent in Norway, and many of the permafrost landforms are ice-cored moraines emerging from smaller cirque glaciers, which end in permafrost (Lilleøren \& Etzelmüller, 2011).

In summary, even with these limitations the countrywide assessment can provide a realistic image of the overall distribution and frequency of steep rock walls in permafrost.

\section{The potential rock wall distribution in Norway}

The potential rock-wall distribution map for Norway (Fig. 1) displays some characteristic patterns that are interesting both for understanding geomorphological processes and for potential hazard assessments. Overall, the highest spatial density of rock walls in permafrost seems to follow an arc around the inner part of Sognefjorden and the Rondane mountains. In northern Norway, permafrost rock walls follow a line from the Lyngen Peninsula to the Narvik region, along the edge of the Caledonides towards the exposed Precambrian basement rock in the east. In general, steep rock walls in Norway are associated with:

(1) U-shaped valleys, eroded during the Pleistocene glaciations, and mountains which protruded as nunataks during the Weichselian and earlier glaciations.
(2) Rock walls related to local glaciations, from both modern and former glacier activity.

(3) Tectonically induced walls related to overthrust nappes.

(4) Rock walls produced by river incision during the Pleistocene and Holocene.

U-shaped valleys dominate along the western part of Norway, following the major drainage routes for the various ice sheets. Since the permafrost limit decreases northwards, possible permafrost in rock walls directly related to U-shaped valleys is more common in northern Norway (Fig. 5) than in southern Norway, where rock walls associated with U-shaped valleys more seldom reach the lower permafrost limit. In southern Norway, permafrost in such settings is mainly found in the Møre and Romsdal county, where valley sides located higher than $1500 \mathrm{~m}$ a.s.l. are common. As both settlements and transport infrastructure are generally situated within the main glacial valleys, the vulnerability to potential permafrost-related rock-wall failure is highest there. In many places, such walls are connected to water bodies such as lakes and fjords, with possible tsunami hazards.

Rock walls associated with former or recent cirques glaciations seem to be the most frequent type. In maritime western Norway, these sites are located in high elevations above $1500 \mathrm{~m}$ a.s.l. and quite commonly related to present glaciations. This includes minor cirques and outlet glaciers from ice caps (Fig. 5). Farther to the east in the Rondane or Sølen mountains, permafrost rock walls are associated with relict cirques. Rock walls related to local glaciations normally exhibit low hazards as these sites are far away from settlements and transport infrastructure.

Walls related to tectonic processes, such as overthrust nappes, are common in central parts of the Caledonian mountain chain. Prominent examples are Hallingskarvet and the Hardanger area in southern Norway (Fig. 5), where metamorphic Precambrian basement rock is thrust above Cambrian phyllite, resulting in kilometrelong continuous rock faces in permafrost.

Rock walls in permafrost originated by river incisions are related to larger canyons. The most prominent examples are the Alta canyon in Finnmark and the valley of the Reisa River in Troms. These large canyons extend into the permafrost zone of central northern Norway.

Comparing our study of the distribution of permafrost rock walls with the topographic classification of Norway (Etzelmüller et al., 2007a), it is evident that permafrost rock walls in southern Norway are mainly associated with high-lying paleic surfaces dissected by local glaciations ('High-mountain' class in Fig. 5), whereas in northern Norway they are mostly associated with alpine terrain dominated by former and present glacial processes ('Alpine' class in Fig. 5). This seems to be 

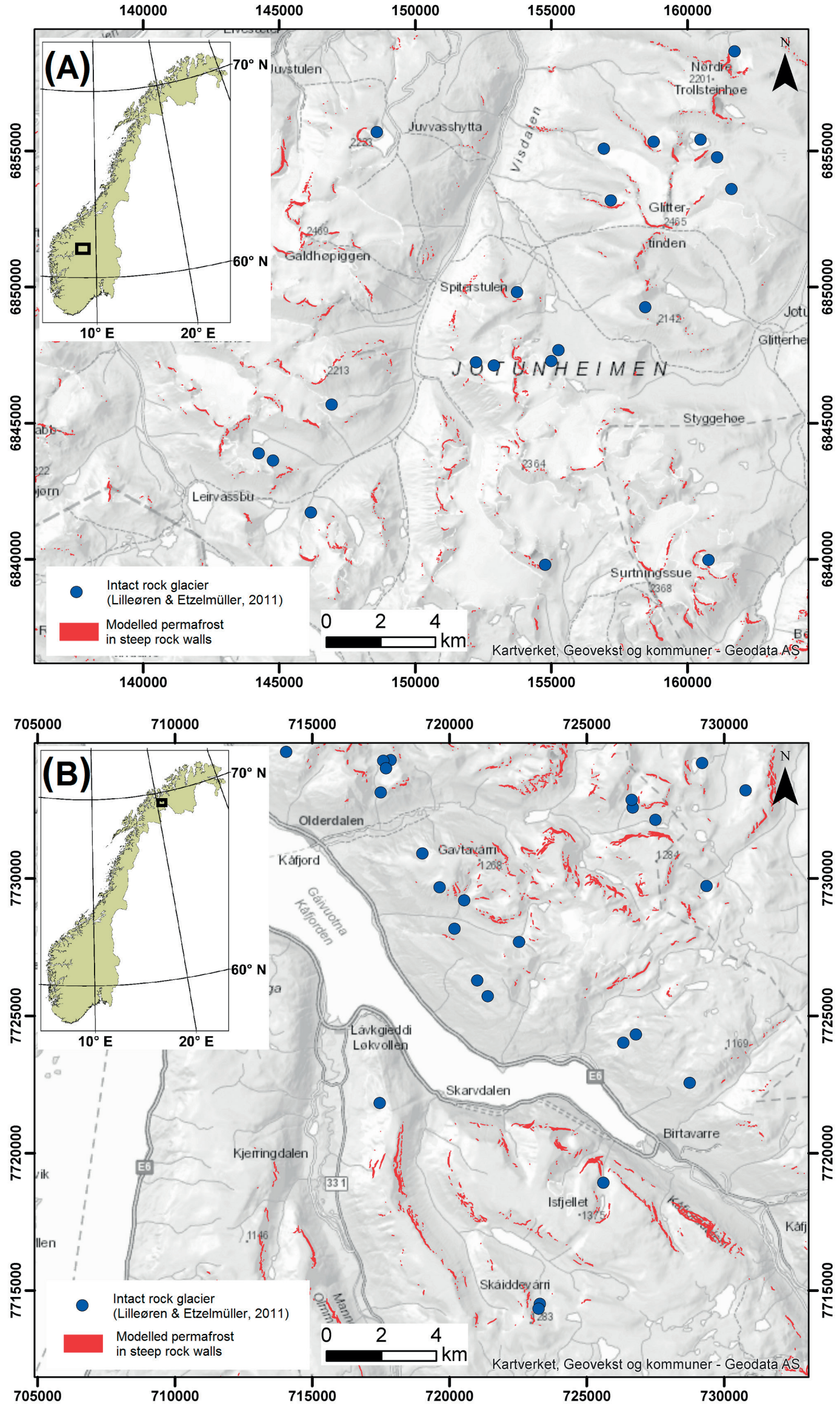

Figure 4. A comparison of modelled potential permafrost in steep rock walls with an inventory of intact rock glaciers and stable ice-cored moraines (based on Lilleøren \& Etzelmüller, 2011) in (A) Southern Norway and (B) Northern Norway. Intact permafrost landforms were categorised as one group, containing both rock glaciers and stable ice-cored moraines. 


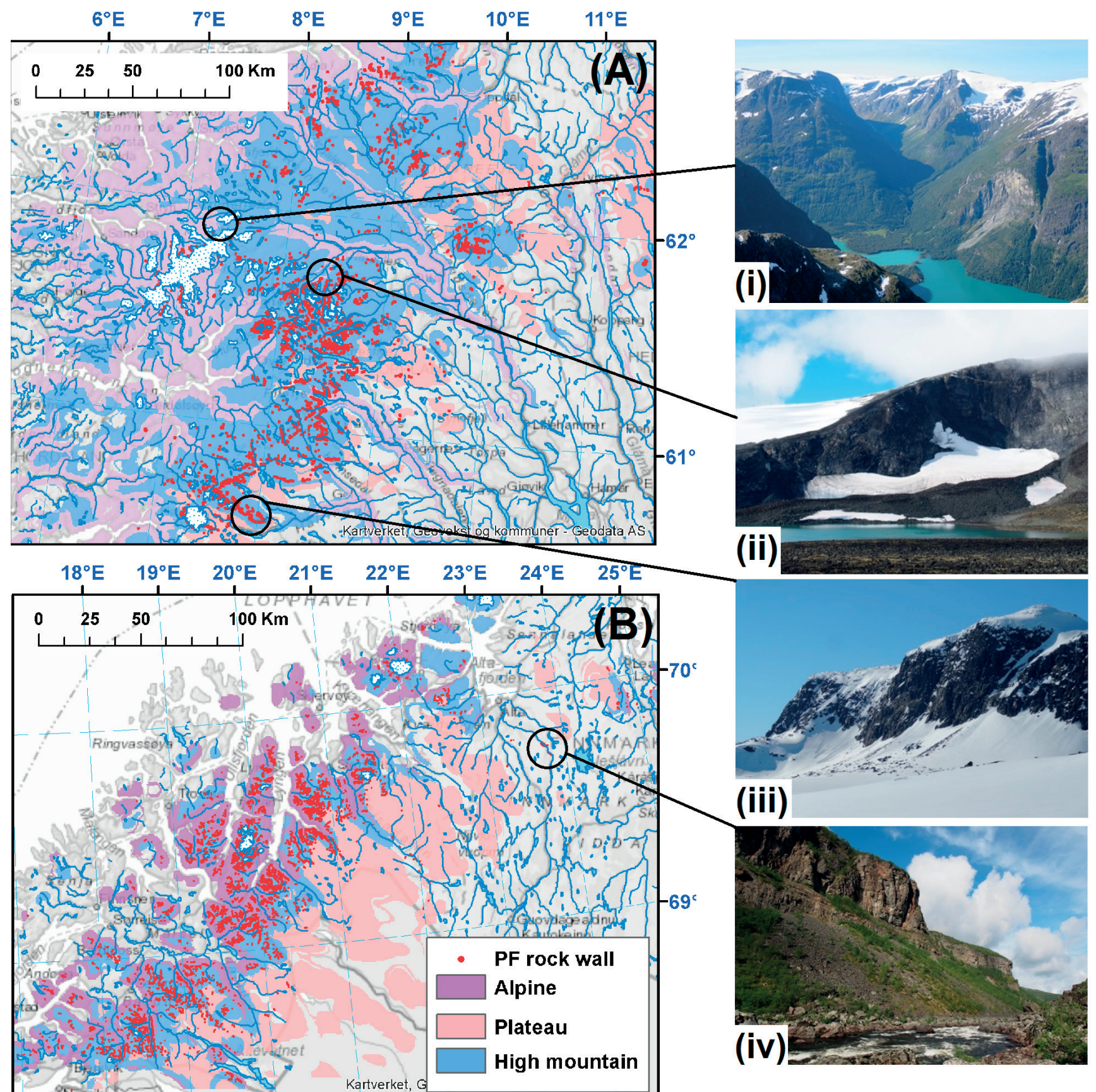

Figure 5. Distribution of steep potential permafrost (PF) rock walls within different topographic classes defined in Etzelmüller et al. (2007a). The 'Alpine' class is dominated by steep slopes and large elevation differences (high local relief), where many U-shaped valleys are found. The 'High-mountain class' has lower local relief and is dominated by a combination of paleic surfaces (e.g., Gjessing, 1967) with imprint of steep relief because of relict or recent local glaciation. The 'Plateau' class summarises high-elevation flat plateaus, and are generally considered as old 'peneplains' (e.g., Gjessing, 1967). These peneplains have low local relief, and are found in different elevation bands throughout Scandinavia: (A) southern Norway permafrost, (B) northern Norway. (i) A U-shaped valley with possible permafrost occurrence in the higher altitudes of the mountain, located northwest of Jostedalsbreen along Lovatnet (photo: Florence Magnin). (ii) The mountain Kjelen (2180 m a.s.l.), Juvflue in central Jotunheimen, is shown as an example of a rock wall associated with recent local glaciation (photo: Bernd Etzelmüller). (iii) A rock wall related to a tectonically overthrust feature, located along Hallinskarvet (photo: Céline Steiger). (iv) The Alta River in Finnmark as an example of a possible permafrost occurrence in a wall produced by river incision (photo: Sebastian Westermann).

simply because in northern Norway, coast-near alpine relief normally reaches elevations of well above 1000 $\mathrm{m}$ a.s.l., and therefore is high enough to extend into the permafrost zone, which in coast-near settings is found above around $800 \mathrm{~m}$ a.s.l. (cf., Christiansen et al., 2010).
In southern Norway, the lower permafrost limit (above $1600 \mathrm{~m}$ in coast-near settings) is mostly located higher than the elevation of alpine relief in western Norway, or in such cases the highest areas are covered by glaciers. 

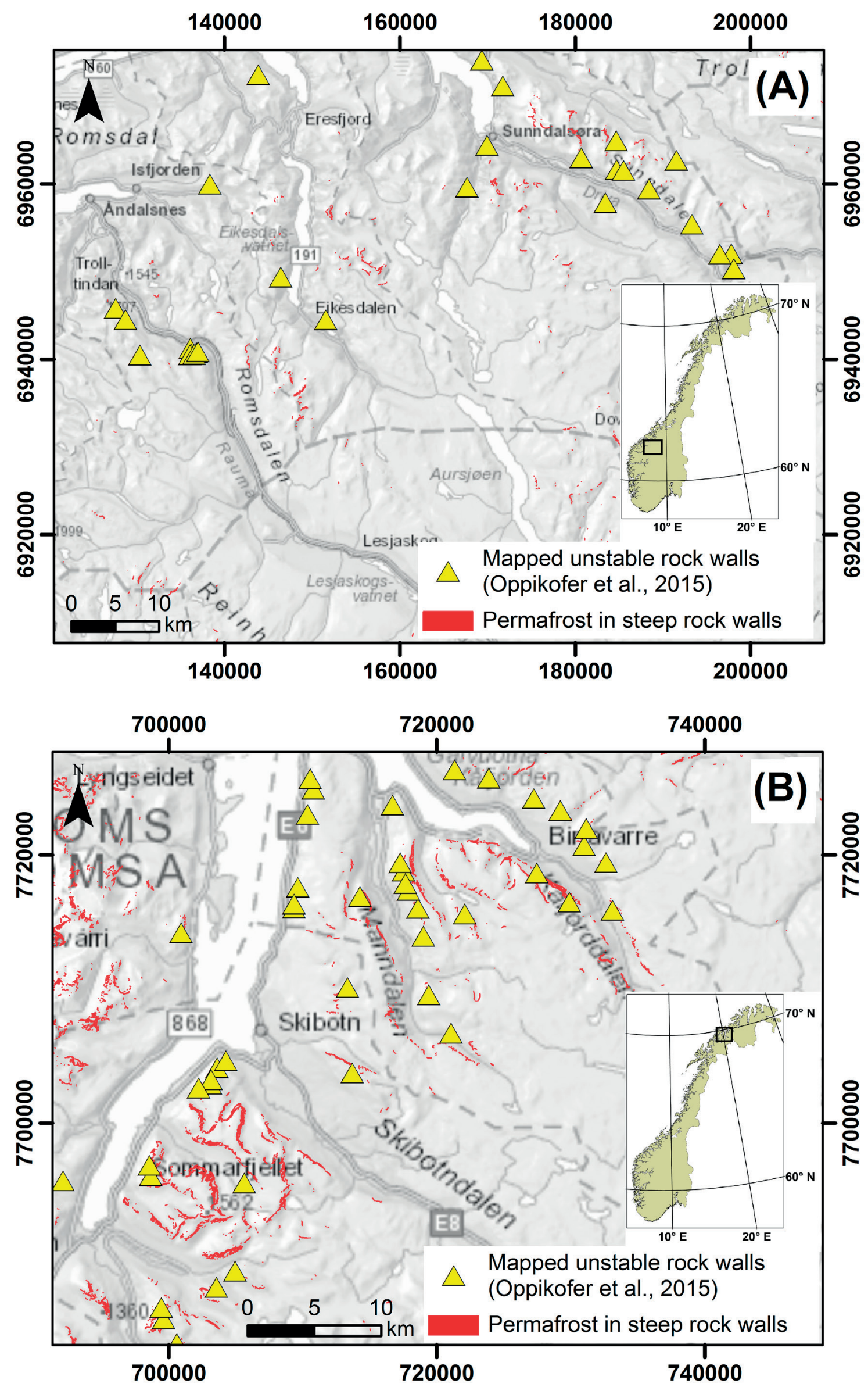

Figure 6. Examples of large unstable rock walls (Oppikofer et al., 2015) mapped in (A) southern Norway in the valleys Sunndalen and Romsdalen; and (B) northern Norway in the Lyngen-Kåfjord area. 


\section{The potential relationship between permafrost and unstable rock slopes in Norway}

We have compared the distribution of potential permafrost rock walls with the inventory of observed rock falls/rock avalanches (https://www.nve.no/flaumog-skred/skrednett/, The Norwegian Water and Energy Directorate - NVE) and large unstable rock slopes (Oppikofer et al., 2015). The general inventory is strongly biased as the recorded events were mostly observed in the vicinity of transport infrastructure. Since most of the possible permafrost rock walls are located away from infrastructure, a general comparison is not possible here.

Large unstable rock slopes are mostly related to nearcoastal sites in alpine terrain, where glaciations or local glaciers have produced oversteepened mountain and valley sides. At such sites, the steep slopes probably still respond to this imbalance in terms of glacially induced oversteepening. Moreover, the structural-tectonic setting at the different sites strongly influences how the slopes react when oversteepened (e.g., Blikra et al., 2006). Our study implies that in southern Norway, the unstable rock slopes are mostly outside the zone of rock walls with permafrost, except along the two large glacial valleys Romsdalen and Sunndalen, and along Jostedalsbreen (Fig. 6). In northern Norway many observed unstable slopes are located close to the modelled permafrost limits in steep slopes. In the continuously monitored rock-slide sites of Nordnes/Jettan (Kåfjord/Lyngen area, Troms county), Blikra \& Christiansen (2014) reported on permafrost occurrences as ice-filled crevasses even below the regional permafrost limit. We assume therefore that the thermal regime may be a factor for slope movement and associated slope stability in many of the mapped unstable rock walls in northern Norway. In southern Norway, only the sites at the highest elevations may be influenced by permafrost.

\section{Conclusions}

The created map of potential occurrence of permafrost in steep rock walls represents a first model of the extent of steep rock walls, which are potentially underlain by permafrost. From this study, the following conclusions can be drawn:

- Permafrost rock walls comprise c. 9\% of all slopes steeper than $60^{\circ}$ in Norway. They are scattered throughout the country, with the highest frequencies in central southern Norway and in the high mountain areas of the Lyngen-Kåfjord area in Troms, northern Norway..

- Locally, up to $20 \%$ of a $1 \mathrm{~km}^{2}$ grid cell can contain steep permafrost rock walls, but normally the frequency is lower.
- The nation-wide model agrees well with local surface temperatures measured in steep rock walls in the Jotunheimen area. The difference between the lower limit of permafrost in south- and north-facing rock walls is around $500-600 \mathrm{~m}$. The comparison with the rock glacier inventory partially supports the potential presence of permafrost in steep rock walls.

- Known unstable rock slopes in northern Norway seem to be close to and below the present lower limit of permafrost (Blikra \& Christiansen, 2014), whereas in southern Norway most of them seem to be outside the permafrost zone, with the exception of just a few sites.

Acknowledgements. This study was funded mainly by the University of Oslo and partly by the CryoWall project ('Steep permafrost slopes in Norway', NFR 243784/CLE). The study is based on a MSc thesis submitted to the Department of Geosciences, University of Oslo by the first author. This manuscript has strongly benefitted by the constructive comments by H.H. Christiansen, an anonymous reviewer and the editor of the NJG. We want to thank all institutions and individuals for their help and support.

\section{References}

Blikra, L.H. \& Christiansen, H.H. 2014: A field-based model of permafrost-controlled rockslide deformation in northern Norway. Geomorphology 208, 34-49. http://dx.doi.org/10.1016/j.geomorph.2013.11.014.

Blikra, L., Longva, O., Braathen, A., Anda, E., Dehls, J.F. \& Stalsberg, K. 2006: Rock slope failures in Norwegian fjord areas: examples, spatial distribution and temporal pattern. In Evans, S.G., Scarascia Mugnozza, G., Strom, A. \& Hermanns, R.L. (eds.): Landslides from massive rock slope failure, Springer, pp. 475-496. http://dx.doi.org/10.1007/978-1-4020-4037-5_26.

Boeckli, L., Brenning, A., Gruber, S. \& Noetzli, J. 2012: A statistical approach to modelling permafrost distribution in the European Alps or similar mountain ranges. The Cryosphere 6, 125-140. http://dx.doi.org/10.5194/tc-6-125-2012.

Chevan, A. \& Sutherland, M. 1991: Hierarchical Partitioning. The American Statistician 45, 90-96.

Christiansen, H.H., Etzelmüller, B., Isaksen, K., Juliussen, H., Farbrot, H., Humlum, O., Johansson, M., Ingeman-Nielsen, T., Kristensen, L., Hjort, J., Holmlund, P., Sannel, A.B.K., Sigsgaard, C., Åkerman, H.J., Foged, N., Blikra, L.H., Pernosky, M.A. \& Ødegård, R.S. 2010: The Thermal State of Permafrost in the Nordic Area during the International Polar Year 2007-2009. Permafrost and Periglacial Processes 21, 156-181. http://dx.doi.org/10.1002/ppp.687.

Davies, M.C.R., Hamza, O. \& Harris, C. 2001: The effect of rise in mean annual temperature on the stability of rock slopes containing icefilled discontinuities. Permafrost and Periglacial Processes 12, 137144. http://dx.doi.org/10.1002/ppp.378.

Etzelmüller, B., Ødegård, R.S., Berthling, I. \& Sollid, J.L. 2001: Terrain parameters and remote sensing in the analysis of permafrost distribution and periglacial processes: Principles and examples from southern Norway. Permafrost and Periglacial Processes 12, 
79-92. http://dx.doi.org/10.1002/ppp.384.

Etzelmüller, B., Berthling, I. \& Sollid, J.L. 2003: Aspects and concepts on the geomorphological significance of Holocene permafrost in southern Norway. Geomorphology 52, 87-104.

http://dx.doi.org/10.1016/S0169-555X(02)00250-7.

Etzelmüller, B., Romstad, B. \& Fjellanger, J. 2007a: Automatic regional classification of topography in Norway. Norwegian Journal of Geology 87, 167-180.

Etzelmüller, B., Farbrot, H., Guðmundsson, Á., Humlum, O., Tveito, O.E. \& Björnsson, H. 2007b: The regional Distribution of Mountain Permafrost in Iceland. Permafrost and Periglacial Processes 18, 185199. http://dx.doi.org/10.1002/ppp.583.

Farbrot, H., Hipp, T., Etzelmüller, B., Isaksen, K., Ødegård, R.S., Schuler, T.V. \& Humlum, O. 2011: Air and ground temperature variations observed along elevation and continentality gradients in Southern Norway. Permafrost and Periglacial Processes 22,343-360.

http://dx.doi.org/10.1002/ppp.733.

Farbrot, H., Isaksen, K., Etzelmüller, B. \& Gisnås, K. 2013: Ground Thermal Regime and Permafrost Distribution under a Changing Climate in Northern Norway. Permafrost and Periglacial Processes 24, 20-38. http://dx.doi.org/10.1002/ppp.1763.

Fischer, L., Purves, R.S., Huggel, C., Noetzli, J. \& Haeberli, W. 2012: On the influence of topographic, geological and cryospheric factors on rock avalanches and rockfalls in high-mountain areas. Natural Hazards and Earth System Sciences 12, 241-254.

http://dx.doi.org/10.5194/nhess-12-241-2012.

Fu, P. \& Rich, P.M. 1999: Design and implementation of the Solar Analyst: An ArcView Extension for Modeling Solar Radiation at Landscape Scales. Proceedings of the Nineteenth Annual ESRI User Conference, San Diego, USA.

Gabrielsen, R.H., Faleide, J.I., Pascal, C., Braathen, A., Nystuen, J.P., Etzelmuller, B. \& O’Donell, S. 2010: Latest Caledonian to Present tectonomorphological development of southern Norway. Marine and Petroleum Geology 27, 709-723.

http://dx.doi.org/10.1016/j.marpetgeo.2009.06.004.

Gisnås, K., Etzelmüller, B., Farbrot, H., Schuler, T.V. \& Westermann, S. 2013: Cryo-GRID 1.0: Permafrost Distribution in Norway estimated by a Spatial Numerical Model. Permafrost and Periglacial Processes 24, 2-19. http://dx.doi.org/10.1002/ppp.1765.

Gjessing, J. 1967: Norway's paleic surface. Norsk Geografisk Tidsskrift 15, 69-132. http://dx.doi.org/10.1080/00291956708621854.

Gruber, S. \& Haeberli, W. 2007: Permafrost in steep bedrock slopes and its temperature-related destabilization following climate change. Journal of Geophysical Research 112.

http://dx.doi.org/10.1029/2006JF000547.

Gruber, S., Hoelzle, M. \& Haeberli, W. 2004: Rock-wall temperatures in the Alps: modelling their topographic distribution and regional differences. Permafrost and Periglacial Processes 15, 299-307. http://dx.doi.org/10.1002/ppp.501.

Haberkorn, A., Hoelzle, M., Phillips, M. \& Kenner, R. 2015: Snow as a driving factor of rock surface temperatures in steep rough rock walls. Cold Regions Science and Technology 118, 64-75. http://dx.doi.org/10.1016/j.coldregions.2015.06.013.

Hallet, B., Walder, J.S. \& Stubbs, C.W. 1991: Weathering by Segregation Ice Growth in Microcracks at Sustained Subzero Temperatures: Verification from an Experimental Study Using Acustic Emissions. Permafrost and Periglacial Processes 2, 283-300. http://dx.doi.org/10.1002/ppp.3430020404.
Hasler, A., Gruber, S. \& Haeberli, W. 2011: Temperature variability and thermal offset in steep alpine rock and ice faces. The Cryosphere 5, 977-988. http://dx.doi.org/10.5194/tc-5-977-2011.

Hipp, T., Etzelmüller, B. \& Westermann, S. 2014: Permafrost in Alpine Rock Faces from Jotunheimen and Hurrungane, Southern Norway. Permafrost and Periglacial Processes 25, 1-13. http://dx.doi.org/10.1002/ppp.1799.

Hughes, A.L.C., Gyllencreutz, R., Lohne, Ø.S., Mangerud, J. \& Svendsen, J.I. 2016: The last Eurasian ice sheets - a chronological database and time-slice reconstruction, DATED-1. Boreas 45, 1-45. http://dx.doi.org/10.1111/bor.12142.

King, L. 1986: Zonation and ecology of high mountain permafrost in Scandinavia. Geografiska Annaler Series A 68, 131-139. http://dx.doi.org/10.2307/521452.

Krautblatter, M., Funk, D. \& Günzel, F.K. 2013: Why permafrost rocks become unstable: a rock-ice-mechanical model in time and space. Earth Surface Processes and Landforms 38, 876-887. http://dx.doi.org/10.1002/esp.3374.

Lilleøren, K.S. \& Etzelmüller, B. 2011: A regional inventory of rock glaciers and ice-cored moraines in Norway. Geografiska Annaler Series A 93, 175-191. http://dx.doi.org/10.1111/j.1468-0459.2011.00430.x.

Lilleøren, K.S., Etzelmüller, B., Schuler, T.V., Gisnås, K. \& Humlum, O. 2012: The relative age of mountain permafrost - estimation of Holocene permafrost limits in Norway. Global and Planetary Change 92-93, 209-223. http://dx.doi.org/10.1016/j.gloplacha.2012.05.016.

Magnin, F., Westermann, S., Pogliotti, P., Ravanel, L., Deline, P. \& Malet, E. in press: Snow control on active layer thickness in steep alpine rock walls (Aiguille du Midi, 3842ma. sl, Mont Blanc massif). Catena. http://dx.doi.org/10.1016/j.catena.2016.06.006.

Oppikofer, T., Nordahl, B., Bunkholt, H., Nicolaisen, M., Jarna, A., Iversen, S., Hermanns, R.L., Böhme, M. \& Molina, F.X.Y. 2015: Database and online map service on unstable rock slopes in Norway - From data perpetuation to public information. Geomorphology 249,69-81. http://dx.doi.org/10.1016/j.geomorph.2015.08.005.

R Core Team 2015: R: A language and environment for statistical computing. R Foundation for Statistical Computing, Vienna, Austria, 3452 pp. https://www.R-project.org/.

Ravanel, L. \& Deline, P. 2011: Climate influence on rockfalls in high-Alpine steep rock-walls: The north side of the Aiguilles de Chamonix (Mont Blanc massif) since the end of the "Little Ice Age". The Holocene 21, 357-365. http://dx.doi.org/10.1177/0959683610374887.

Romanovsky, V.E., Smith, S.L. \& Christiansen, H.H. 2010: Permafrost thermal state in the polar Northern Hemisphere during the international polar year 2007-2009: a synthesis. Permafrost and Periglacial Processes 21, 106-116. http://dx.doi.org/10.1002/ppp.689.

Saloranta, T.M. 2012: Simulating snow maps for Norway: description and statistical evaluation of the seNorge snow model. The Cryosphere 6, 1323-1337. http://dx.doi.org/10.5194/tc-6-1323-2012.

Sollid, J.L. \& Sørbel, L. 1979: Deglaciation of western central Norway. Boreas 8, 233-239. http://dx.doi.org/10.1111/j.1502-3885.1979.tb00805.x.

Tveito, O.E., Førland, E.J., Heino, R., Hanssen-Bauer, I., Alexandersson, H., Dahlström, B., Drebs, A., Kern-Hansen, C., Jónsson, T., Vaarby Laursen, E. \& Westman, Y. 2000: Nordic temperature maps. Det norske meteorologiske institutt Report no. 09/00, 54 pp. 
Tveito, O.E., Bjørdal, I., Skjelvåg, A.O. \& Aune, B. 2005: A GIS-based agroecological decision system based on gridded climatology. Meteorological Applications 12, 57-68.

http://dx.doi.org/10.1017/S1350482705001490.

Walsh, C. \& Mac Nally, R. 2008: The hier.part Package. Variance partition of a multivariate data set version 1.0-3.

https://cran.r-project.org/web/packages/hier.part/hier.part.pdf.

Westermann, S., Schuler, T.V., Gisnås, K. \& Etzelmüller, B. 2013: Transient thermal modeling of permafrost conditions in Southern Norway. The Cryosphere 7, 719-739.

http://dx.doi.org/10.5194/tcd-6-5345-2012.

Zevenbergen, L.W. \& Thorne, C.R. 1987: Quantitative analysis of land surface topography. Earth Surface Processes and Landforms 12, 47-56. http://dx.doi.org/10.1002/esp.3290120107. 